\title{
Klamydia eller chlamydia, uretritt eller urethritt?
}

K er som regel å foretrekke fremfor ch i norsk ortografi, og «hjelpebokstaver» trengs ikke.

Tidsskriftet oppmuntrer til å bruke norsk rettskrivning når det er naturlig, men har vært merkelig konservativ i skrivemåten av genital klamydiainfeksjon.

\section{Klamydia}

Bakterien som forårsaker klamydiainfeksjon heter Chlamydia trachomatis, men på norsk bør bakterien hete klamydiabakterie. Sykdommen som forårsakes av $\mathrm{C}$ trachomatis må hete klamydia eller klamydiainfeksjon. Denne skrivemåten blir allerede brukt av Folkehelsa (1). Man kan også betegne en person med positiv klamydiaprøve som klamydiapositiv, i stedet for chlamydiapositiv, som det står i Tidsskriftets ordliste. Ordlisten inneholder ordet klamydial, som er inkonsekvent når ordet klamydia ikke anbefales. Dette ordet, $i$ betydningen klamydial infeksjon, blir sjelden brukt. Det gir ingen treff når jeg søker på ordet i Tidsskriftet. Bruken av chlamydia er ikke konsekvent i Tidsskriftet, chlamydia gir 99 treff på artikkelsøk, og klamydia seks treff.

Hvis man søker på Google, viser det seg at de aller fleste, både norske og svenske nettsider, bruker klamydia som skrivemåte. For eksempel nettdoktor.no, som skriver: «Klamydia er en sykdom som skyldes bakterien Chlamydia trachomatis» (2). I Sverige har man i over 20 år skrevet klamydia. I Smittskyddslagen fra 1988 brukes ordet «Klamydiainfektion» (3).

\section{Uretritt}

Den vanligste manifestasjon av betennelse som forårsakes av klamydia, er uretritt. Her bruker Tidsskriftet den latinske/engelske skrivemåten urethritt. Ifølge Tidsskriftets ordliste begrunnes dette som følgende: «urethra (alle ord vedrørende urethra skri-

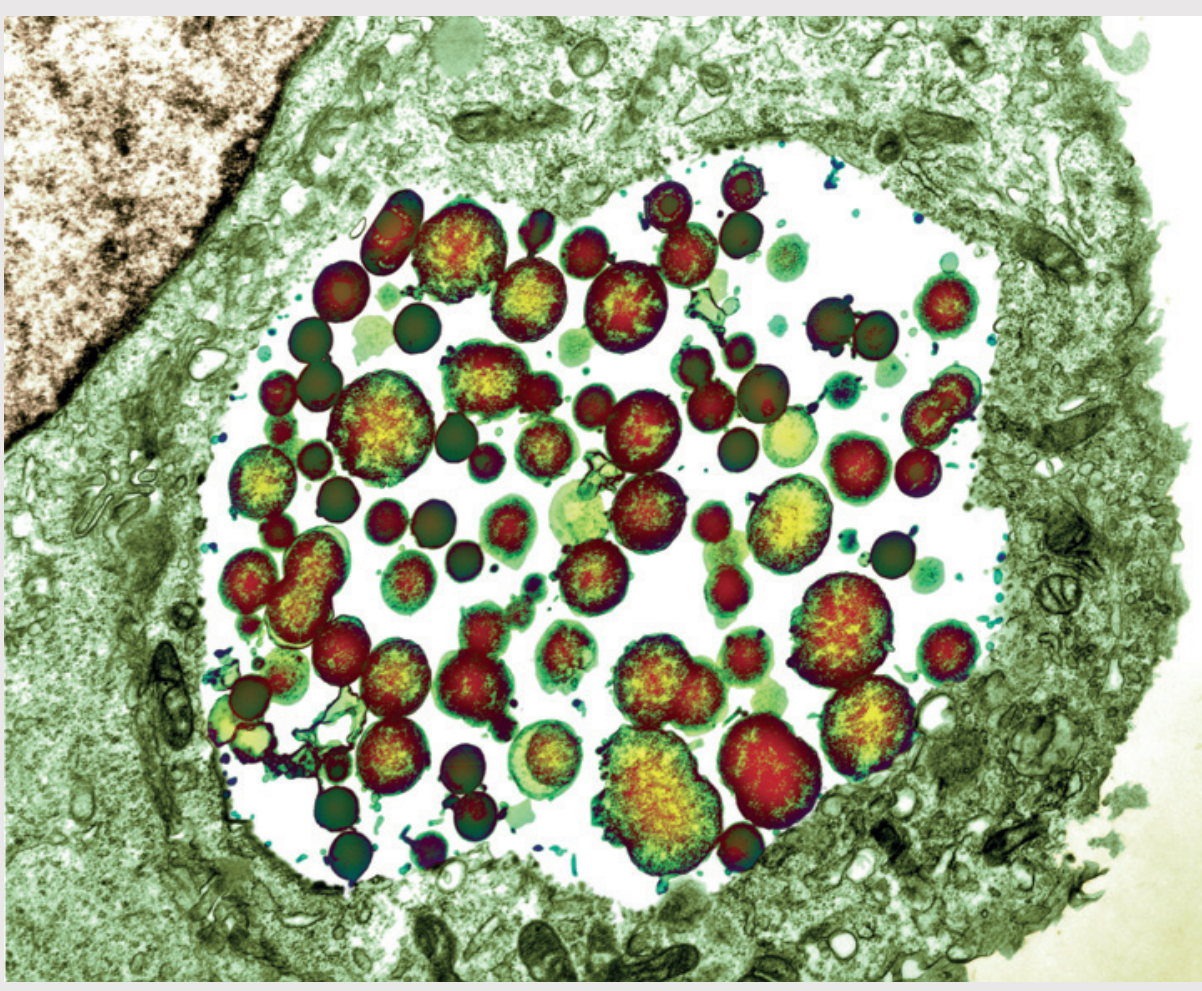

Klamydiabakterien inne i en celle. Foto Science Photo Library/Scanpix ves med h for å unngå forveksling med ureter)». Betennelse i ureteren, urinlederen mellom nyrebekken og urinblære, er imidlertid en sjelden diagnose, som ikke kan stilles med en enkel klinisk undersøkelse og mikroskopi, som betennelse i urethra, uretritt. Ved søk i Tidsskriftet er det seks treff på urethritt og ett treff på ureteritt. Det siste er dessverre en skrivefeil, det skulle stått urethritt (1). Søk på uretritt gir ti treff. Dette viser dels at Tidsskriftet ikke er konsekvent i skrivemåten av urethritt/ uretritt, og at ureteritt overhodet ikke er blitt beskrevet i Tidsskriftet, og derfor neppe gir grunn til forveksling med uretritt.

Som en følge av å sløyfe h i urethritt, må også følgende ord fra ordlisten skrives uten h: uretral, uretrodyni, uretrografi, uretrometer, uretroskopi.

\section{Harald Moi \\ harald.moi@medisin.uio.no \\ Olafiaklinikken \\ Oslo universitetssykehus \\ og \\ Det medisinske fakultet \\ Universitetet i Oslo}

Harald Moi (f.1942) er spesialist i hud- og veneriske sydommer, med spesialkompetanse i venerologi. Han er overlege på Olafiaklinikken, professor II ved Universitetet i Oslo og medlem av redaktørkomitéen for europeiske retningslinjer for diagnostikk og behandling av seksuelt overførte infeksjoner.

\footnotetext{
Litteratur

1. Moi H. Hvilken prøve er best for å påvise genital chlamydiainfeksjon? Tidsskr Nor Lægeforen 2011 131: 1279.

2. Fakta om klamydia. www.nettdoktor.no/ sykdommer/fakta/klamydia.php (9.3.2012]

3. Rättsnätet. Smittskyddslag (1988: 1472). www.notisum.se/rnp/sls/lag/19881472.htm (9.3.2012).
}

Mottatt 8.1. 2012, første revisjon innsendt 1.2. 2012, godkjent 6.3. 20112. Medisinsk redaktør Raida Ødegaard. 